\title{
In vitro digestion of protein-enriched restructured beef steaks with pea protein isolate, rice protein and lentil flour following sous vide processing
}

\author{
Sephora Baugreet ${ }^{\mathrm{a}, \mathrm{c}}$, Carolina Gomez ${ }^{\mathrm{b}}$, Mark A.E. Auty ${ }^{\mathrm{b}}$, Joseph P. Kerry ${ }^{\mathrm{c}}$, Ruth M. Hamill ${ }^{\mathrm{a}}$, \\ André Brodkorb ${ }^{\mathrm{b}, *}$
}

a Teagasc Food Research Centre, Ashtown Dublin 15, Ireland
$\mathrm{b}$ Teagasc Food Research Centre, Moorepark, Fermoy, Co. Cork, Ireland
${ }^{\mathrm{c}}$ School of Food and Nutritional Sciences, Food Science Building, University College Cork, Ireland

\section{A R T I C L E I N F O}

\section{Keywords:}

Protein-enriched meat

Sous vide processing

Transglutaminase

In vitro digestion

Static digestion

Food structure

Bioaccessibility

\begin{abstract}
A B S T R A C T
The effect of plant protein inclusion in cooked meat upon in vitro gastro-intestinal (GI) digestion was investigated. Pea protein isolate, rice protein and lentil flour were used to increase the protein content in a meat model system restructured using two transglutaminase enzymes [Activa ${ }^{\circledR} \mathrm{EB}$ (TG) and Transgluseen ${ }^{\mathrm{TM}}-\mathrm{M}$ (TS)]. Restructured beef steaks were subjected to simulated GI digestion using the static INFOGEST method. Samples taken at different digestion times were analysed using SDS-PAGE, size exclusion-HPLC, free amino acid analysis and microscopy. SDS-PAGE analysis revealed significant protein hydrolysis during GI digestion. Most soluble peptides had a molecular weight smaller than $500 \mathrm{Da}$, corresponding to peptides of $<5$ amino acids, regardless of food treatment. The amounts of released, free amino acids isoleucine, lysine, phenylalanine and valine were higher $(P<0.05)$ in lentil-enriched restructured beef steaks following GI digestion. Confocal laser scanning microscopy (CSLM) revealed pronounced aggregation in digested samples. In vitro digestates of protein-enriched restructured beef steaks showed lower production of small molecular weight peptides. This study demonstrated how the bioaccessibility of protein-enriched restructured beef steaks are influenced by formulation and processing.
\end{abstract}

\section{Introduction}

Protein plays a key role in health, growth, development and active ageing from birth to the older years. High-protein products are gaining awareness among consumers who seek easily recognisable, simple and calorifically-lowered high protein based foodstuffs. Ageing influences the gastrointestinal digestion (digestion, absorption, excretion) of nutrients (Baker \& Blakely, 2017). In older adults, a loss a muscle proteins, consequently leads to depletion of muscle mass known as sarcopenia (Walrand et al., 2016). The nutritional quality of protein can be defined by its digestibility in the intestinal phase, which is correlated to amino acid (AA) uptake. It is worthwhile to note that AA availability is dependent on composition and content of dietary proteins, nonetheless choosing proteins with different digestion rates could also promote postprandial stimulation of protein synthesis in older adults (Walrand et al., 2016). This was demonstrated in a study by Nowson and O'Connell (2015) who showed that, muscle gain was greater among older adults receiving whey protein (rapidly-digested protein) and lower when offered casein (slowly-digested protein). Therefore, fast digesting proteins might be more beneficial than slow-digesting proteins to improve postprandial protein anabolism in older adults.

Meat is a commonly-consumed commodity worldwide among all consumer age groups. Meat is a rich source of high-quality protein and all the essential amino acids required for adult human needs (WHO/ FAO/UNU, 2007). In recent times, lower-value meat such as chuck and round have been highlighted as potential underutilised food sources due to their technological and nutritional properties. These cuts were mostly used and sold as ground meat, sausages, meatballs, frankfurters, patties, luncheon meat and pâtés (Olmedilla-Alonso, JiménezColmenero, \& Sánchez-Muniz, 2013). In addition to their nutrient-rich profile, different meat cuts could be fortified to produce healthier formulations targeting specific populations or nutritional deficiencies.

$\mathrm{Pi}-\mathrm{Vac}$ technology, a novel processing application in reformed formulations combined with plant-based proteins and specific nutrients allow for the development of restructured meat products, which can help meet specific nutritional goals, such as targeted protein content. The combination of restructuring and the Pi-Vac technology can facilitate the development of low cost, controlled portion size meat products

\footnotetext{
* Corresponding author.

E-mail address: andre.brodkorb@teagasc.ie (A. Brodkorb).
} 
from low-value cuts and trimmings (Baugreet, Kerry, Allen, Gallagher, \& Hamill, 2018). The use of transglutaminase enzyme in restructured meat formulations is well-established to achieve desired quality for example cohesion, cook yield and palatability (Carballo, Ayo, \& Colmenero, 2006).

Plant-based proteins are rapidly becoming mainstream ingredients not only for sports enthusiasts, but also for the rapidly growing, older global population (Mintel., 2013). Successful plant-based ingredients, such as plant proteins or flours, must retain suitable functional properties within meat-based products such as solubility, emulsification and gelation (Söderberg, 2013), as well as contributing to the nutritional and sensorial characteristics of the product. Additionally, plants like legumes can also supply significant amounts of various dietary protein fractions; such as globulins, albumins, glutelins and prolamins. The relative proportion of each of these fractions in different legumes defines the nutritional quality of the legume, based on its amino acid composition (Tiwari \& Singh, 2012). Literature concerning the technofunctional properties of incorporating plant proteins in meat systems has accumulated in recent years. In restructured beef products, plantbased proteins have generally been utilised to improve cooking yields, water/fat binding and sliceability (Söderberg, 2013; Tahmasebi, Labbafi, Emam-Djomeh, \& Yarmand, 2016; Youssef \& Barbut, 2011). However, some undesirable effects have also been observed relating to flavour, texture, uniformity and overall acceptability when plant-based proteins were used (Peng, Dayton, Quass, \& Allen, 1982).

In general, meat is a consistent source of indispensable amino acids while plant proteins are lacking in sulphur-containing amino acids (methionine, cysteine and tryptophan). Combined in the proper proportions, plant-based proteins, in addition to meat, may ensure the right balance of all essential amino acids required for the human diet as recommended by the WHO/FAO/UNU (2007). An understanding of the molecular interaction that occurs when plant-based proteins are incorporated into a meat system is necessary in order to improve the technology required for optimal use and manipulation of plant derivatives in processed meats, such that the resulting functional characteristics are improved upon or similar to that expected in conventionally produced commercial processed meat products.

The basic mechanisms affecting plant-based and meat protein digestive behaviour is important to understand, as this knowledge may be applied to guide the development of novel protein-enhanced meat products with improved digestibility. Bolus formation and disintegration of food are important in the overall digestion process especially for solid foods, as the structure of the bolus strongly affects the rate of digestion during the rest of the gastro-intestinal transit. For the purpose of this study, chew and spit method was used to better mimic oral disintegration.

Earlier studies by Baugreet et al. (2018), showed that the inclusion of plant-derived protein ingredients [pea protein isolate (PPI), rice protein (RP) and lentil flour (LF)] at $4 \%$ and $8 \%$ and two binding agents: ActivaEB 1\% (TG), and TrangluseenTM-M 0.15\% (TS) exhibited beneficial physicochemical properties. The inclusion of rice protein and pea protein isolate enhanced the protein content in restructured beef steaks, however, this increase was more pronounced with RP at $8 \%$ inclusion level. While this level was beneficial from a nutritional perspective, it also increased hardness. On the other hand, lentil-treated restructured beef steaks with TG or TS provided a softening effect on tenderness but did not increase protein content relative to controls. To the author's knowledge no comprehensive study has been carried out to study the effect of plant protein inclusion on protein digestion and microstructure of a restructured beef steak following sous vide processing. The effects of changes in the restructured steak formulation and/ or processing on digestive enzymes and on its protein network structure and resulting polypeptide profile and free amino acid profile were analysed.

\section{Materials and methods}

\subsection{Materials}

Analytical grade trichloroacetic acid, potassium chloride, monopotassium phosphate, sodium bicarbonate, sodium chloride, magnesium chloride hexahydrate, ammonium carbonate, calcium chloride, hydrochloric acid, sodium hydroxide, bovine bile extract, porcine pepsin, pancreatin and pefabloc ${ }^{\circledast}$ protease inhibitor and other chemicals were purchased from Sigma Aldrich (St Louis, MO, USA), unless mentioned otherwise. Pea protein isolate ( $83 \%$ protein) was supplied by Redbrook Ingredients (Dublin, Ireland) and rice protein (79\% protein) and lentil flour (Lens esculenta, $23.8 \%$ protein) from Healy Group (Dublin, Ireland). Transglutaminase enzyme Activa ${ }^{\circledR} \mathrm{EB}$ (TG) was obtained from Ajinomoto Europe (Hamburg, Germany) and TransgluseenTM-M (TS) from Siveele, Breda (The Netherlands).

\subsection{Methods}

\subsubsection{Preparation of restructured beef steaks}

This experiment included three ingredients (pea protein isolate [P], rice protein $[R]$, lentil flour $[\mathrm{L}]$ ) at two inclusion levels (4 and $8 \%$ ), with two binders added to each ingredient at each level (Activa ${ }^{\mathrm{EB}}{ }^{\mathrm{B}}$ [TG] and Transgluseen ${ }^{\mathrm{TM}}-\mathrm{M}$ [TS]). Control samples were prepared with restructured meat without the addition of plant proteins and binders. The treatments were as follows; Control (C), P4TG, P4TS, P8TG, P8TS, R4TG, R4TS, R8TG, R8TS, L4TG, L4TS, L8TG and L8TS. These treatments were prepared according to a recent publication by Baugreet et al. (2018). All restructured steak samples were subjected to below analysis were cooked in sous vide pouches (OPA/PP $15 / 75,100-180^{\circ} \mathrm{C}$, Versatile Packaging, Dublin, Ireland) at $75{ }^{\circ} \mathrm{C}$ for $12 \mathrm{~h}$ in a water bath.

\subsubsection{In vitro digestion}

The in vitro digestion of cooked restructured steak was performed according to a standardised method, specifically designed for studying simulated gastrointestinal digestion of food (Brodkorb et al., 2019; Minekus et al., 2014) with some modifications. Digestions consisted of an enzymatic digestion simulating the mouth, stomach and small intestine. Briefly, meat samples of approximately $2.5 \mathrm{~g}$ were subjected to 'chew and spit' method performed by only one person (the first author), rather than simulated oral digestion. The food was chewed until they reached the urge to swallow, but was expectorated instead and reweighed again (Woolnough, Bird, Monro, \& Brennan, 2010). For solid foods, a 'chew and spit' method can be more accurate in simulating the oral phase (Wickham, Faulks, \& Mills, 2009) compared to the recommended grinding of the food recommended in the INFOGEST method (Minekus et al., 2014). Each sample was then placed in a centrifuge tube and placed on ice until use. About $2.4 \mathrm{~mL}$ simulated gastric fluid (pH 3) at $37^{\circ} \mathrm{C}$ was added to the tubes, followed by porcine pepsin activity (to achieve $2000 \mathrm{U} / \mathrm{mL}$ ) and $1.5 \mu \mathrm{L}$ of calcium chloride ( $150 \mu \mathrm{M}$ final concentration). This was followed by an acidification step to $\mathrm{pH} 3$ using $2 \mathrm{M} \mathrm{HCI}$, thus initiating the gastric digestion process. At the end of gastric digestion $(0,30,60,90,120 \mathrm{~min})$, to inactivate pepsin and to simulate digestion in the small intestine $\mathrm{pH}$ was adjusted to 7 . The digestion samples were preserved after $0,30,60,90,120 \mathrm{~min}$ of incubation at $37{ }^{\circ} \mathrm{C}$ in a rotator. To end the gastric phase, $1 \mathrm{M}$ sodium hydroxide was used to increase $\mathrm{pH}$ to 7 and the sample was snap-frozen in liquid nitrogen. For the intestinal phase, $3.8 \mathrm{~mL}$ of simulated intestinal fluid was added; $0.6 \mathrm{~mL}$ of bile salt $(10 \mu \mathrm{M}$ final concentration) was added, as well as $1 \mathrm{~mL}$ of pancreatin to achieve a trypsin activity of $100 \mathrm{U} / \mathrm{mL}$. The $\mathrm{pH}$ was further increased to $\mathrm{pH} 7$ for each sample using $1 \mathrm{M}$ sodium hydroxide and placed in a $37^{\circ} \mathrm{C}$ incubator on a rotator. The final volume of each digested sample (digesta) was approximately $12 \mathrm{~mL}$. Upon completion of the intestinal phase, an inhibitor (Pefabloc $^{\circledast}$ ) was added at $20 \mu \mathrm{L}$, followed by immediate snap-freezing using liquid nitrogen $\left(\mathrm{N}_{2}\right)$. The procedure is also described in great detail as 
online video protocol (YouTube channel "In vitro food digestion - COST action INFOGEST").

\subsubsection{SDS - polyacrylamide gel electrophoresis (SDS-PAGE)}

Firstly, plant-based ingredient samples ( $50 \mu \mathrm{g}$ each); lentil flour, rice protein and pea protein isolate were dissolved in distilled water and Laemmli sample buffer $(50 \mu \mathrm{L} \beta$-mercaptoethanol, $950 \mu \mathrm{L}$ Laemmli sample buffer) and heated at different time-points (10, 20, 30, 40, $60 \mathrm{~min})$ at $95{ }^{\circ} \mathrm{C}$. Aliquots taken from restructured meat samples at different digestion time points were evaluated by 1D-SDS PAGE. Prior to analysis, all proteins were estimated by using Protein A280 NanoDrop spectrophotometers. $50 \mu \mathrm{g}$ of meat samples were dissolved in distilled water and Laemmli sample buffer $(50 \mu \mathrm{L} \beta$-mercaptoethanol, $950 \mu \mathrm{L}$ Laemmli sample buffer) and heated for $10 \mathrm{~min}$ at $95^{\circ} \mathrm{C}$. $\beta$ Mercaptoethanol act as a reducing agent by cleaving the disulphide bonds between proteins. Samples were then centrifuged $(10,000 \times g$, $10 \mathrm{~min}$ ) and analysed by SDS-PAGE according to Laemmli (1970), using precast gels (Mini-PROTEAN Tetra Cell System, TGX Gels, 4-20\% acrylamide linear gradient, Bio-Rad, USA). The loading volume was $20 \mu \mathrm{L}$ in each well. The gels were run at constant $100 \mathrm{~V}$ for about $115 \mathrm{~min}$. Protein bands were stained with Coomassie Brilliant Blue R-250 (BioRad, USA) for $2 \mathrm{~h}$ and then destained by soaking in 10\% methanol:10\% acetic acid: $\mathrm{H}_{2} \mathrm{O}$ (3:2:5 by volume) for $30 \mathrm{~min}$ at two intervals. The gels were then scanned using a densitometric scanner (GS-800 Bio-Rad) and analysed qualitatively.

\subsubsection{Size exclusion HPLC (SEC-HPLC)}

Molecular weight distribution of the soluble fraction of the digested and undigested food was determined by size exclusion chromatography (TSKgel $2000 \mathrm{SW}_{\mathrm{XL}}, 7.8 \mathrm{~mm} \times 600 \mathrm{~mm}$; Tosh Biosciences $\mathrm{GmbH}$, Stuttgart, Germany) using a high-performance liquid chromatography (HPLC) system as previously described by Sullivan et al. (2014). The mobile phase (isocratic elution) consisted of $30 \%(\mathrm{v} / \mathrm{v})$ acetonitrile containing $0.1 \%(\mathrm{v} / \mathrm{v})$ trifluoroacetic acid (TFA) at a flow rate of $0.5 \mathrm{~mL} \mathrm{~min}^{-1}$ and monitored at a wavelength of $214 \mathrm{~nm}$. The samples were diluted in water and $20 \mu \mathrm{L}$ of $1 \mathrm{~g} \mathrm{~L}^{-1}$ protein solutions were injected into the column. The molecular weight distribution was determined by integrating the relevant area under the chromatogram using the Empower Pro5 software (Waters, Milford, USA). A molecular weight calibration was prepared using the following seven standards: bovine serum albumin $(66.7 \mathrm{kDa}), \beta$-lactoglobulin (18.4 kDa), carbonic anhydrase $(29.0 \mathrm{kDa})$, aprotinin $(6511 \mathrm{Da})$, insulin (3496 Da), bacitracin (1422 Da) and dipeptide His-Leu (268 Da) (all Sigma-Aldrich, Dublin, Ireland). All samples and standards were pre-filtered through $0.22 \mu \mathrm{m}$ low protein binding membrane filters (Sartorius Stedim, UK) prior to application to the column. All solvents were filtered under vacuum through $0.45 \mu \mathrm{m}$ high-velocity filters (Millipore Ltd., UK).

\subsubsection{Release of free amino acid during in vitro gastrointestinal digestion}

The free amino acids were analysed according to a previous described method by McDermott et al. (2016). Amino acid analysis was carried out on samples at selected timepoints (at the start and after $120 \mathrm{~min}$ of digestion). 24\% TCA was prepared by dissolving $24 \mathrm{~g}$ TCA in $100 \mathrm{~mL}$ of distilled water. Digested samples for each timepoint were mixed thoroughly using a vortex, $750 \mu \mathrm{L}$ of each sample was placed in a $1.5 \mathrm{~mL}$ eppendorf tube, followed by $750 \mu \mathrm{L}$ of $24 \%$ TCA. This mixture was mixed and allowed to stand for $10 \mathrm{~min}$. Samples were centrifuged for $10 \mathrm{~min}$ at $4000 \mathrm{~g}$. Supernatants were quantified using a Jeol JLC500/V amino acid analyser (Jeol (UK) Ltd., Garden city, Herts, UK) fitted with a Jeol $\mathrm{Na}^{+}$high-performance cation exchange column.

\subsubsection{Confocal laser scanning microscopy}

Gastric and intestinal meat samples were subjected to microstructural analysis. $20 \mu \mathrm{L}$ of sample was placed on a microscope slide and $5 \mu \mathrm{L}$ of Nile Blue (aqueous, $0.1 \% \mathrm{w} / \mathrm{w}$ ) added to the samples. A cover slip was placed on top of all samples and they were imaged in a
Leica SP5 confocal scanning laser microscope (Leica Microsystems $\mathrm{GmBH}$, Mannheim, Germany). Dual channel images were acquired with a $\times 10, \times 20$ and $\times 63$ objectives, using a $488 \mathrm{~nm}$ argon ion laser to image fat (green) and a $633 \mathrm{~nm}$ helium neon laser to image protein, myofibrils and connective tissue.

\subsubsection{Statistical analysis}

Free amino acid data were analysed by analysis of variance (ANOVA). The data was analysed as a $3 \times 2 \times 2$ factorial omitting control treatments and analysed separately for gastric and intestinal phase. Significant differences among treatments were assessed using Tukey test, the level of significance was set at $P<0.05$. Data analyses were performed using GenStat Statistical Package (Release 14.1, Hertfordshire, UK).

\section{Results and discussion}

\subsection{SDS-PAGE analysis of ingredients, undigested, gastric and intestinal digested samples}

Electrophoretic patterns of lentil flour, rice protein and pea protein isolate as ingredients analysed at different time-points $(10,20,30,40$, $60 \mathrm{~min}$ ) when heated at $95^{\circ} \mathrm{C}$ is shown in Fig. 1. Globulins and albumins are the major components of pulse proteins. Globulins are available as subunits $11 \mathrm{~S}$ with a molecular mass of approximately $40 \mathrm{kDa}$ (acidic) and $20 \mathrm{kDa}$ (basic). These subunits can be seen among $\mathrm{L}$ and $\mathrm{P}$ samples across the different time-points. Vicilins (7S), also present in globulins with a molecular mass of $175-180 \mathrm{kDa}$, were not evident in the samples tested. Tiwari and Singh (2012), stated that some pulse proteins contain either $11 \mathrm{~S}$ or $7 \mathrm{~S}$ subunits exclusively. Another protein band observed was convicilin, a third major storage protein at $71 \mathrm{kDa}$ in $\mathrm{L}$ and $\mathrm{P}$. This finding is also in accordance with findings reported by Tiwari and Singh (2012) and Barac et al. (2010). Bands were seen in the $\mathrm{R}$ and $\mathrm{P}$ samples at the top of the stacking gel. This indicates high molecular weight aggregates or the presence of poorly soluble proteins (Pietrysiak, Smith, Smith, \& Ganjyal, 2018). At $40 \mathrm{~min}$, the separations of bands in the pea protein isolate were clearer. After prolonged heattreatment of $\mathrm{L}$ samples, a reduction in bands was observed, while in $\mathrm{R}$ samples the band at $\sim 25 \mathrm{kDa}$ was denser at $40 \mathrm{~min}$.

SDS-PAGE profiles, as affected by the addition of $\mathrm{P}, \mathrm{R}$ and $\mathrm{L}$ (at 4 to $8 \%$ ) to restructured beef steaks mixtures mediated by TS/TG (at 1 and 2.5\%; respectively/undigested) are illustrated in Fig. 2A. The analysis of the extracted protein showed that bands with molecular weights of $200 \mathrm{kDa}$ myosin heavy chains (MHC) was only faintly visible in proteinenriched formulations; clearly illustrating a reduction in the bands as a result of the addition of TS/TG and protein ingredients. The undigested control contains two bands in close proximity, larger than $116 \mathrm{kDa}$. One of these could be $\beta$-actinin (130 kDa), however, mass spectrometry would be necessary to identify the proteins (Kaur, Maudens, Haisman, Boland, \& Singh, 2014). However, after addition of plant P or L and transglutaminase enzyme, only one bands appears, which may be due to covalent crosslinking.

The only differences evident in band intensities were dependent on the relative content of the protein components in the mixture. Another reason for lower band intensities could be associated with the long cooking time used in this study resulting in additional cross-linkage formations between proteins. The results obtained in this study were similar to that reported by Li et al. (2017). The cross-linked proteins may not have entered the SDS-PAGE gel (4-12\%) and consequently, remained in the stacking gel. Rice-treated restructured beef steaks at $8 \% \mathrm{TS} / \mathrm{TG}$ revealed an appearance of new bands which were evident in the lower molecular weight region (6 to $21 \mathrm{kDa} \mathrm{M}_{\mathrm{w}}$ ) (Fig. 2A).

SDS profiles of samples after gastric digestion showed the presence of major bands corresponding to proteins and peptides with a $\mathrm{M}_{\mathrm{w}}$ smaller than $50 \mathrm{kDa}$ (Fig. 2B). Most protein bands larger than $50 \mathrm{kDa}$, which were clearly visible in the undigested samples, have disappeared, 


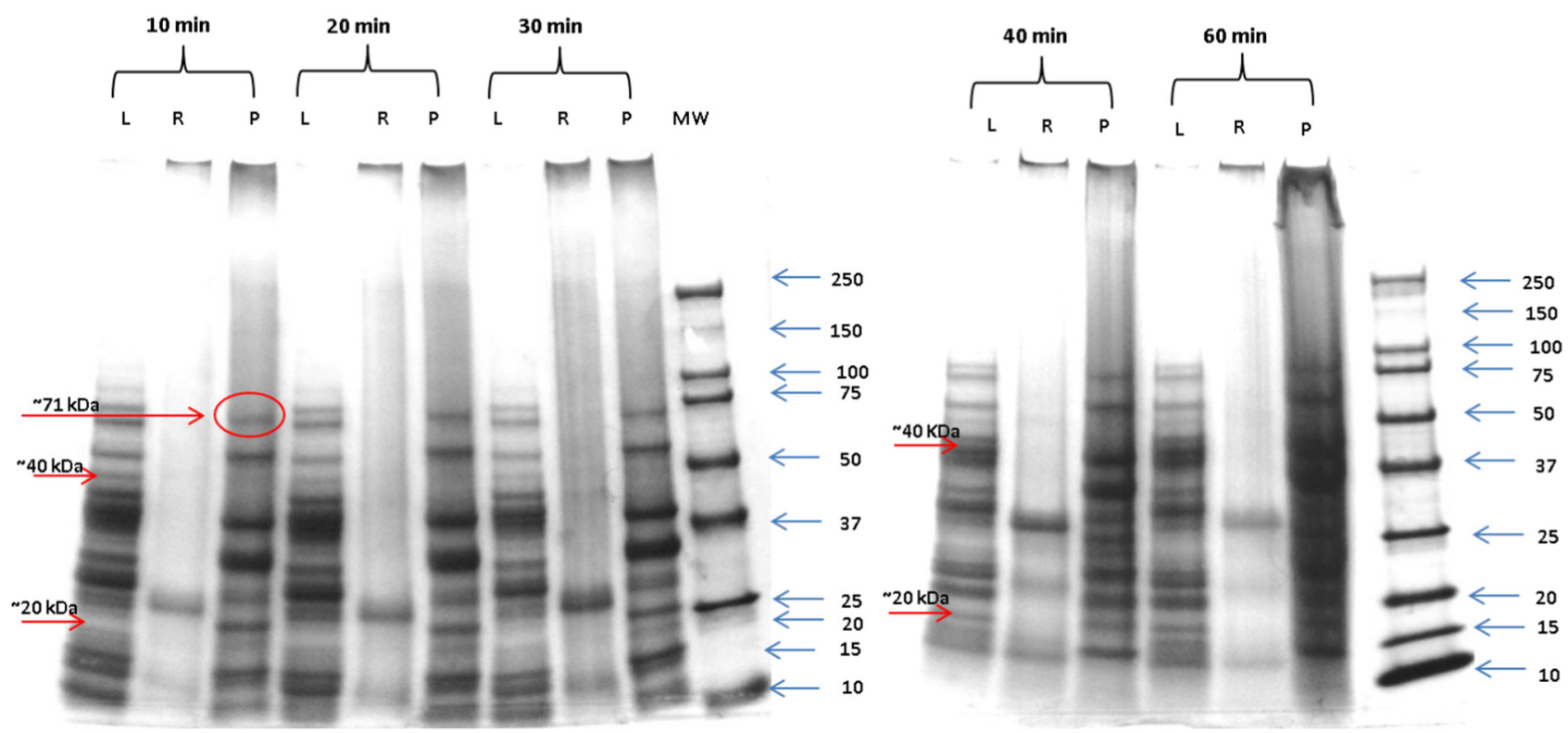

Fig. 1. Effect of cooking time on the SDS-PAGE patterns of protein ingredients: lentil flour (L), rice protein (R) and pea protein isolate (P) heated for 10, 2030 , 40, $60 \mathrm{~min}$ at $95^{\circ} \mathrm{C}$

i.e., were digested by the gastric enzymes. The bands at $37 \mathrm{kDa}$, $25-20 \mathrm{kDa}$ and $15 \mathrm{kDa}$ (Fig. 2A) which appeared in undigested samples were also present in the gastric samples. However, these bands were present at much lower intensities. This indicates that the enzyme pepsin could degrade a certain amount of these proteins. Treatment P8TG still showed the lighter bands between 50 and $37 \mathrm{kDa}$ and $15 \mathrm{kDa}$. Control,
R4TS and L8TG had higher band intensities that could be associated with the degradation of proteins bands with higher molecular weight. Profiles were similar to other studies suggesting that bands at $37 \mathrm{kDa}$ correspond to acidic subunits and a predominance of bands at 25 to $20 \mathrm{kDa}$ may be attributed to $\alpha$ and $\beta$ subunits of legumin protein (Pastor-Cavada, Juan, Pastor, Alaiz, \& Vioque, 2010). Numerous
A

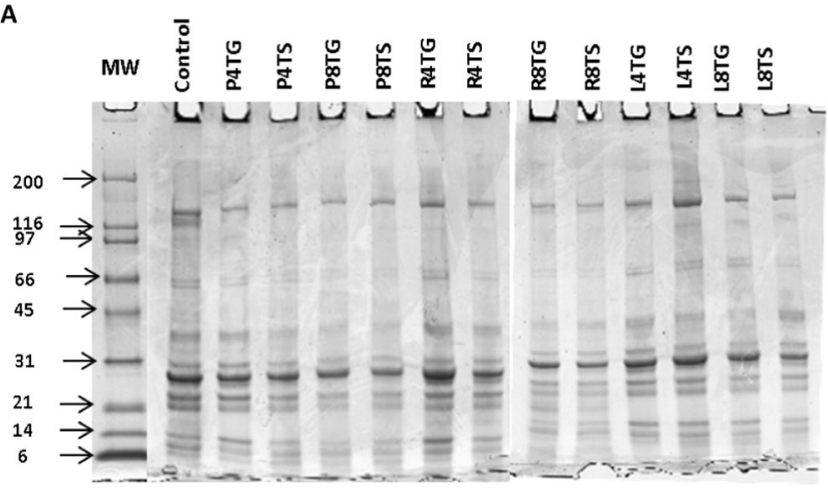

B

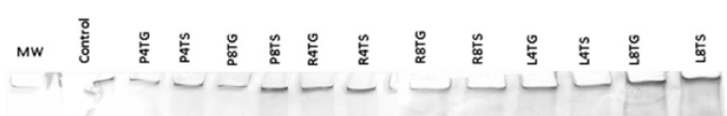

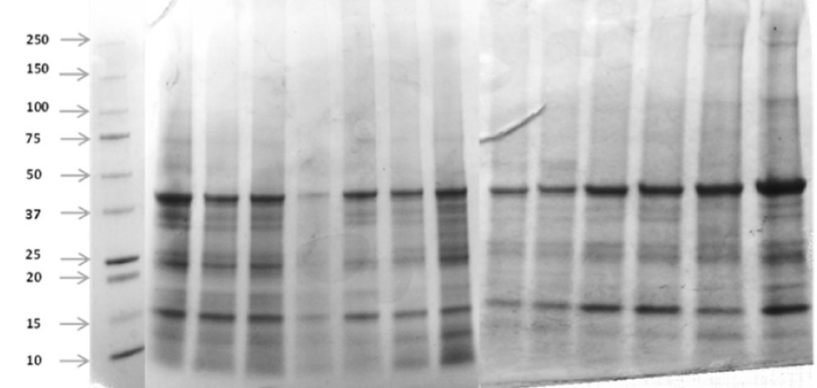

Fig. 2. (A-C) SDS-PAGE patterns of protein-enriched restructured beef steaks; a) undigested, b) after gastric digestion, c) after intestinal digestion. MW - molecular weight marker in $\mathrm{kDa}$; control (CP), inclusion of pea protein isolate (P), rice protein (R) and lentil flour (L) (at 4 and $8 \%$ ); binding agents: Activa ${ }^{\mathrm{EB}}$ (TG), and Trangluseen ${ }^{\mathrm{TM}}-\mathrm{M}$ (TS). 


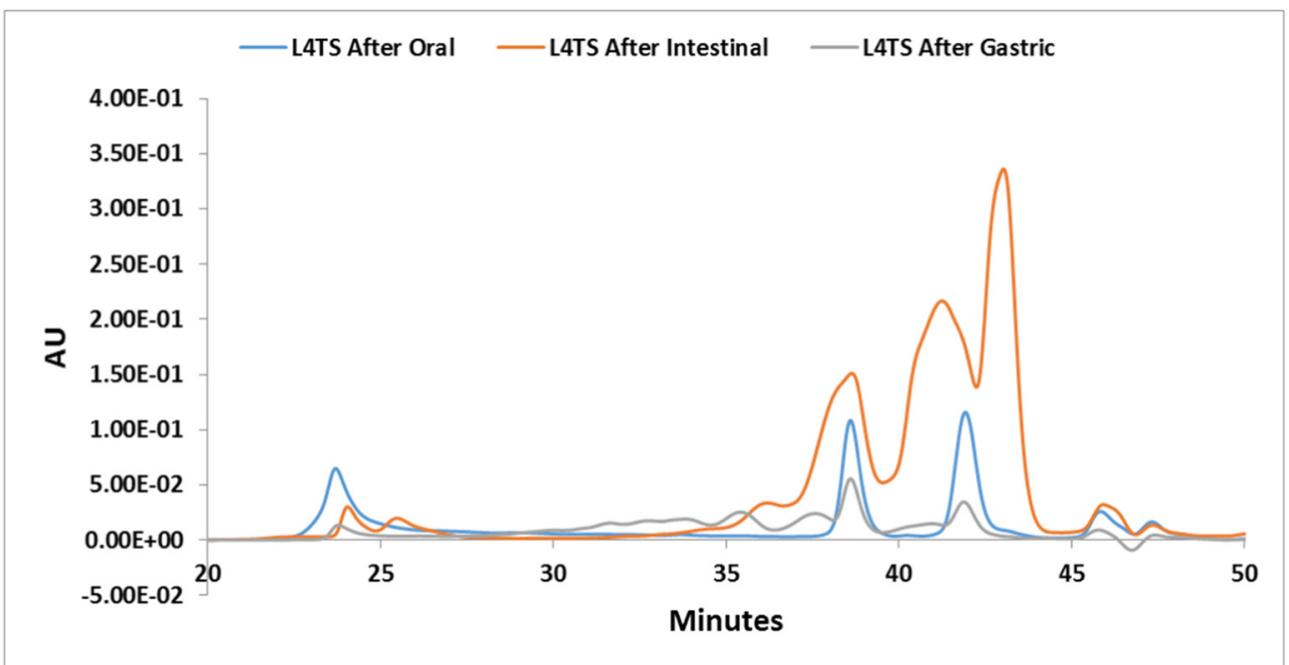

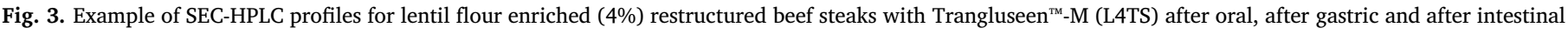
digestion; Elution time (minutes) and absorbance (AU).

smaller molecular weight fragments were also visible in the SDS-PAGE gels.

After intestinal digestion, high molecular weight protein bands disappeared except those at $50 \mathrm{kDa}$ to $\sim 75 \mathrm{kDa}$, which could be derived from larger proteins such as nebulin and titin (Fig. 2C). Plant proteins such as those from peas contain major storage proteins known as legumin (11S), vicilin (7S) and another 7S globulin known as convicilin (Barac et al., 2010). Convicilin has a $\mathrm{M}_{\mathrm{w}}$ of $\sim 290 \mathrm{kDa}$ and is composed of subunits with a $\mathrm{M}_{\mathrm{w}}$ of $71 \mathrm{kDa}$, which can be identified in Fig. 2C. This is in agreement with Kaur, Rutherfurd, Moughan, Drummond, and Boland (2010). Smaller bands could be attributed to the pancreatic enzymes (e.g. trypsin $23 \mathrm{kDa}$, chymotrypsin $25 \mathrm{kDa}$ ). It should be noted that peptides smaller than $8 \mathrm{kDa}$ are often not detectable by SDS-PAGE.

\subsection{Size exclusion HPLC}

Fig. 3 shows examples of the SEC-HPLC chromatograms for formulation L4TS. It clearly showed the general increase in detected proteins and peptides at lower $\mathrm{M}_{\mathrm{w}}$ after gastric and intestinal digestion compared to those samples after oral mastication. Fig. 4 presents the molecular weight distribution of the soluble fractions of protein-enriched restructured beef steaks, which ranged from $>20 \mathrm{kDa}$ to $<$ $500 \mathrm{Da}$ after the oral (Fig. 4A), gastric (Fig. 4B) and intestinal phase (Fig. 4C). To quantitatively assess the size distribution data, profiles were split into six molecular weight intervals $(<500 \mathrm{Da}, 0.5-1 \mathrm{kDa}$, $1-5 \mathrm{kDa}, 5-10 \mathrm{kDa}, 10-20 \mathrm{kDa},>20 \mathrm{kDa}$ ) and the normalised value of each material was quantified based on the area under the curve. It should be noted that only water-soluble proteinaceous material, filtered through $0.45 \mu \mathrm{m}$ membranes, can be detected by SEC-HPLC hence relatively low amount of soluble protein and peptides were detected. After the oral phase, all samples exhibited a similar trend as regards to the smaller peptide fractions of $0.5-5 \mathrm{kDa}$ and $5-10 \mathrm{kDa}$ (Fig. 4A). P4TS, L8TG and L8TS contained more $>20 \mathrm{kDa}$ peptides when compared to controls. Peptides of $<500 \mathrm{Da}$ increased dramatically with pea- and rice-treated samples at $4 \%$ with TG/TS and in lentil-treated samples at 8\% TG/TS. R8TS, L4TG and L4TS contained lower < $500 \mathrm{Da}$ fractions when compared with controls.

After the gastric phase, samples treated with TG were higher bands around molecular weight intervals (1-5 kDa), while TS-treated samples were present in lower amounts, with the exception of L8 TG/TS treated samples (Fig. 4B). A similar trend was also observed in only pea-treated samples at $<500 \mathrm{Da}$. The fractions with 10 to $>20 \mathrm{kDa}$ increased in L8TS samples, while fractions between 0.5 to $5 \mathrm{kDa}$ and $<500 \mathrm{Da}$ decreased.

After the intestinal phase, peptides $>5 \mathrm{kDa}$ were present in lower amounts in all samples. Peptides ranging 0.5 to $1 \mathrm{kDa}$ were slightly lower in samples P8TG, L4TG and L4TS when compared to controls (Fig. 4C). Control samples contained the maximal number of $>20 \mathrm{kDa}$ and $<500 \mathrm{Da}$ peptides in comparison to other treatments. For peatreated samples at 4 and $8 \%$ inclusion levels with TG, a reducing trend was observed for peptides $<500 \mathrm{Da}$, while the opposite effect was observed in P4TS and P8TS. Peptides of $<500$ Da decreased consecutively in R4TG, R4TS and R8TG treated samples. For lentil-treated samples, $<500$ Da fractions were abundant at $8 \%$ inclusion levels for both TG/TS.

Peptides of $<500$ Da were present in all treated sample after in vitro GI digestion. The presence of these smaller peptides indicates that the samples were very susceptible to proteolytic breakdown. This indicates that as digestion progresses, pepsin enzyme cleaves more peptide sites, consequently an increase of soluble oligopeptides of varying sizes are produced (Opazo-Navarrete, Schutyser, Boom, \& Janssen, 2017). Smaller peptides have been previously shown to exert higher antioxidant activity than larger peptides (Damgaard, Lametsch, \& Otte, 2015). The presence of smaller peptides in this study are indicative of how proteins can be broken down, resulting in an increase in water soluble peptide fraction, which are generally regarded as bioaccessible, i.e. accessible for absorption through the gut wall thus exerting their nutritional and biological function.

\subsection{Free amino acid produced during in vitro gastrointestinal digestion}

Regarding the free amino acid composition of protein-enriched restructured beef steaks, only significant differences between ingredient, levels and binder used were presented (Table 1). There was no statistical difference among treated samples and controls (data not presented). Among all free amino acids analysed only when lentil flour was added threonine content was higher $(P<0.05)$ in comparison to peaand rice-treatments after gastric digestion. After intestinal digestion, this increase remained higher in lentil treated samples for isoleucine, lysine, phenylalanine and valine. Isoleucine and lysine was observed to be higher in the presence of TS. It is important to identify the chemical integrity of the amino acids especially after digestion i.e. resistance to processing, heat and pH (Friedman, 1996). The presence of partly hydrolysed protein from plant protein inclusion in a meat product may be a considerable portion of the total protein. This can be considered part of the dietary fibre composite or indigestible fraction, caused by 


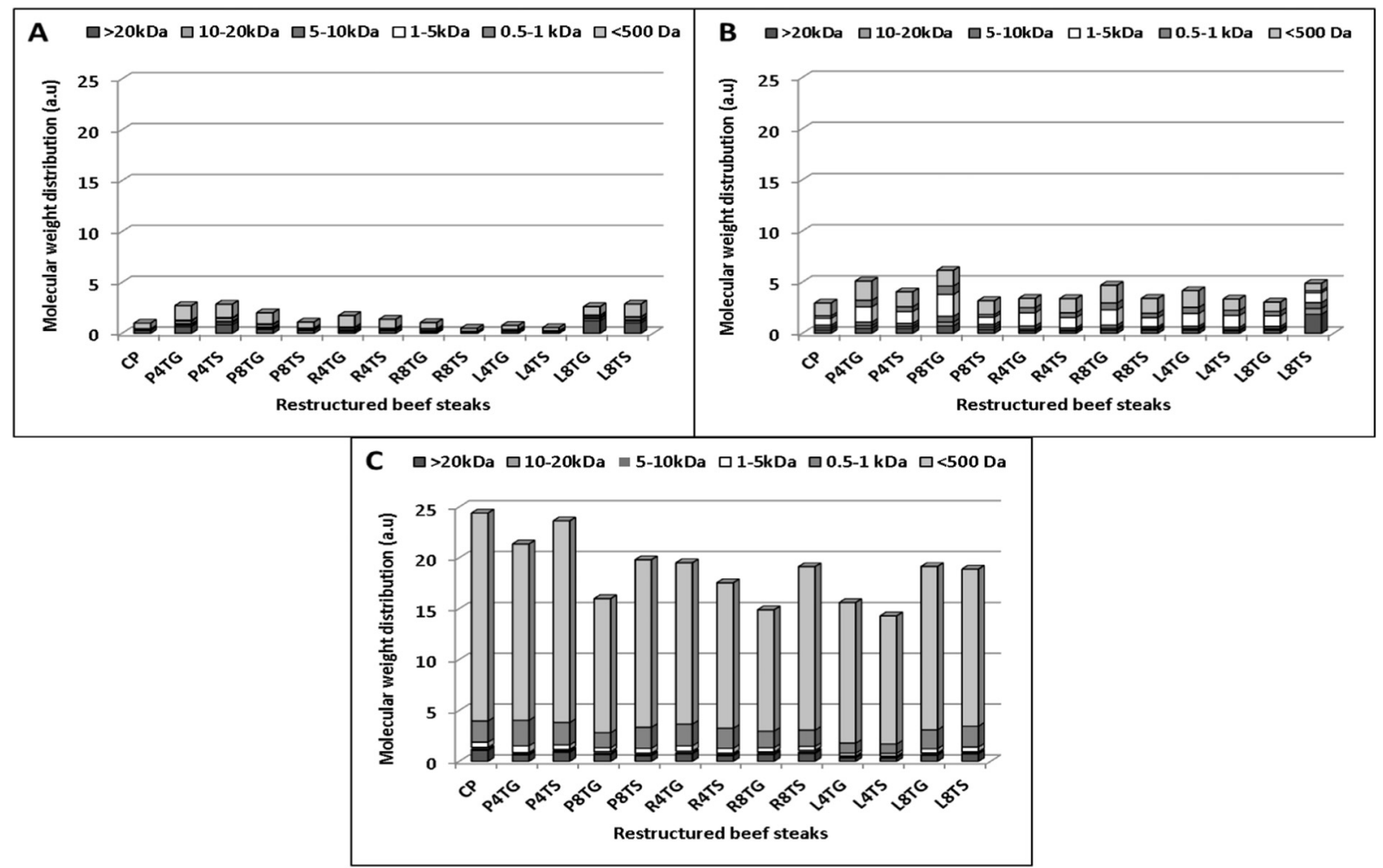

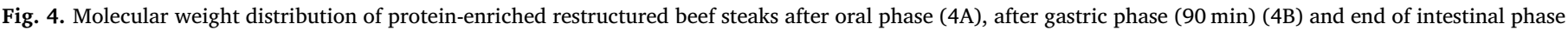

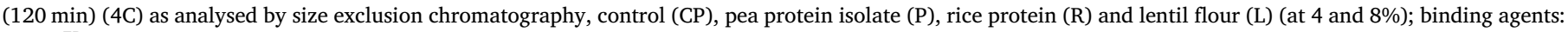
Activa $^{\mathrm{EB}}$ (TG), and Trangluseen ${ }^{\mathrm{TM}}-\mathrm{M}$ (TS).

protease inhibitor-protease complexes (Friedman, 1996). This could also be explained by the action of endopeptidases causing the initial protein fragments to be further degraded to smaller peptides and free amino acids.

\subsection{Microstructural analysis}

The above results dealt with the soluble proteinaceous fraction of the food samples before and after digestion with the exception of SDSPAGE, where samples were exposed to SDS-containing sample buffer. While these chemical analyses are important, it is also essential to consider the insoluble food micro-structure, which determines the

Table 1

Changes in released free amino acid from protein-enriched restructured beef steaks during gastrointestinal digestion.

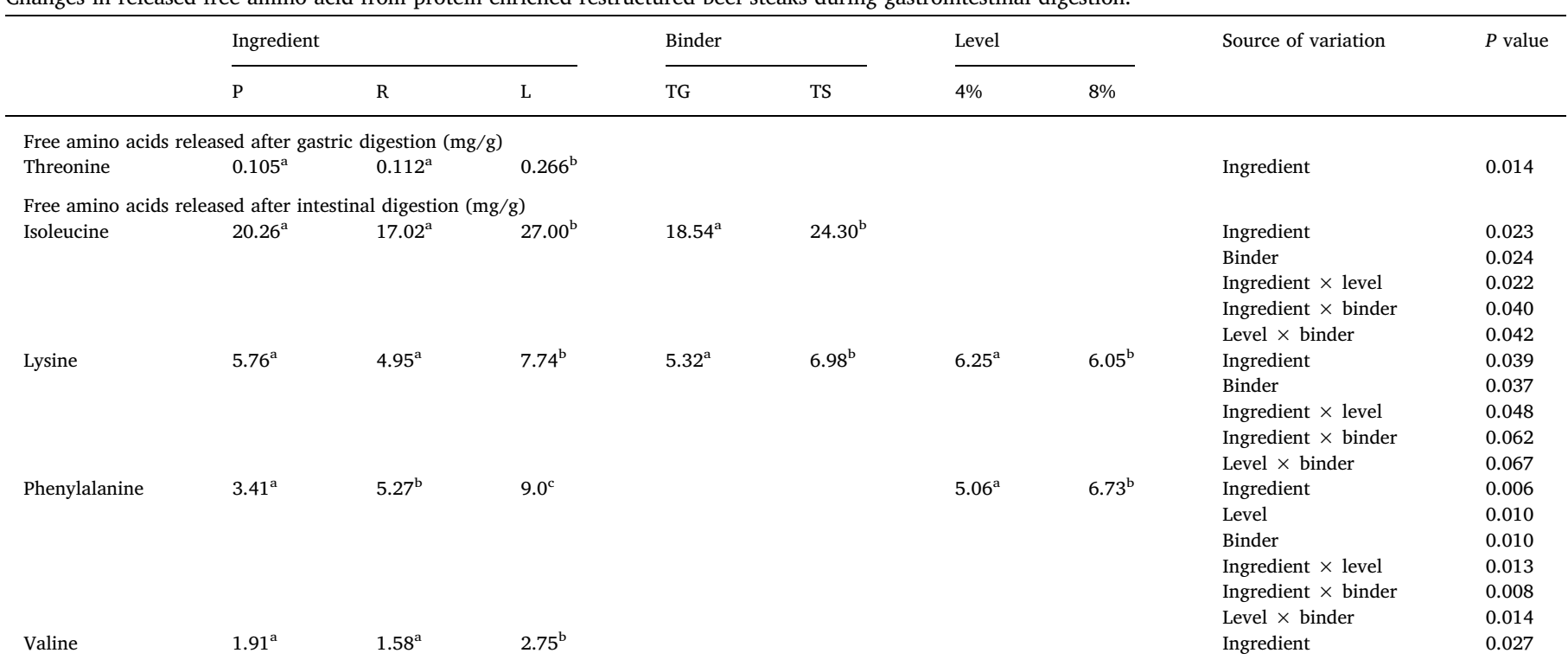

${ }^{\mathrm{a}-\mathrm{c}}$ Means in the same row with different superscript letters differ significantly $(P<0.05)$; only significant values presented; pea protein isolate $(\mathrm{P})$, rice protein $(\mathrm{R})$ and lentil flour (L) (at 4 and 8\%); binding agents: Activa $^{\mathrm{EB}}$ (TG), and Trangluseen ${ }^{\mathrm{TM}}-\mathrm{M}$ (TS). 

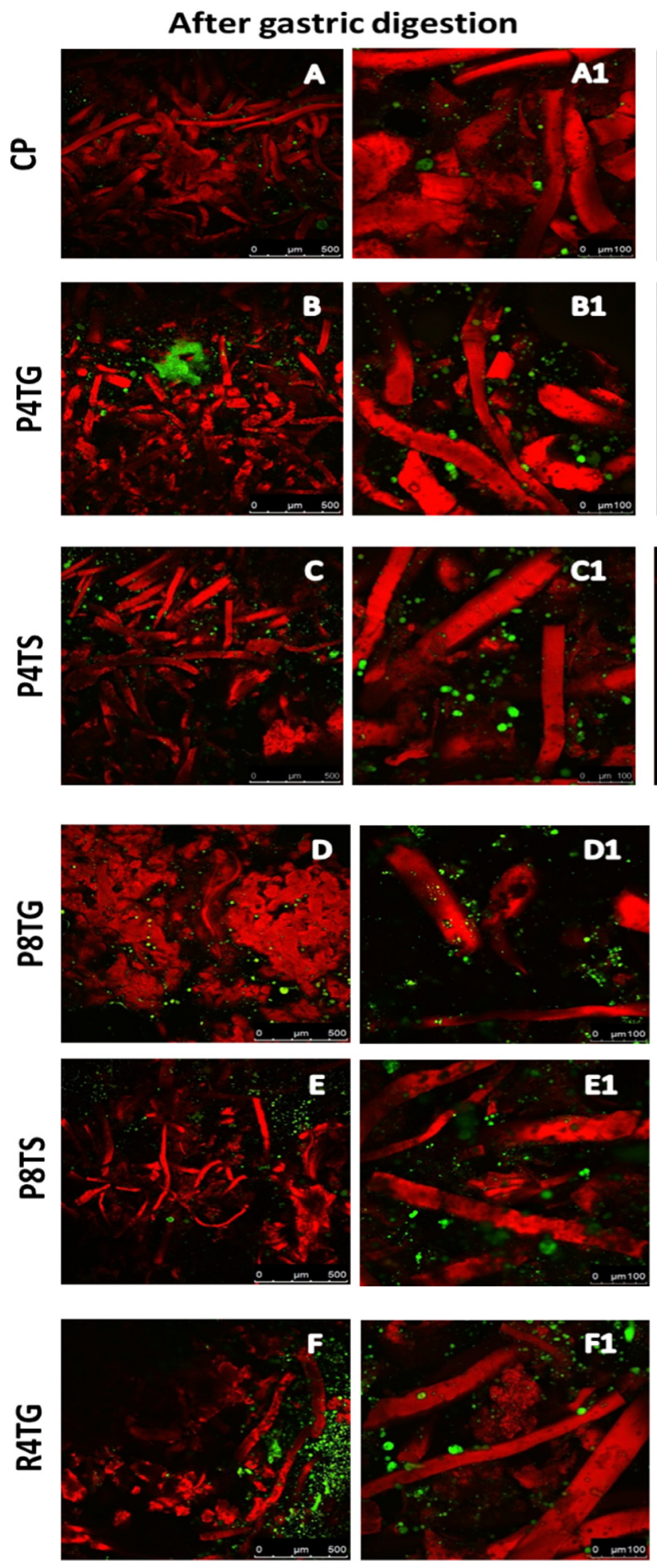

After intestinal digestion
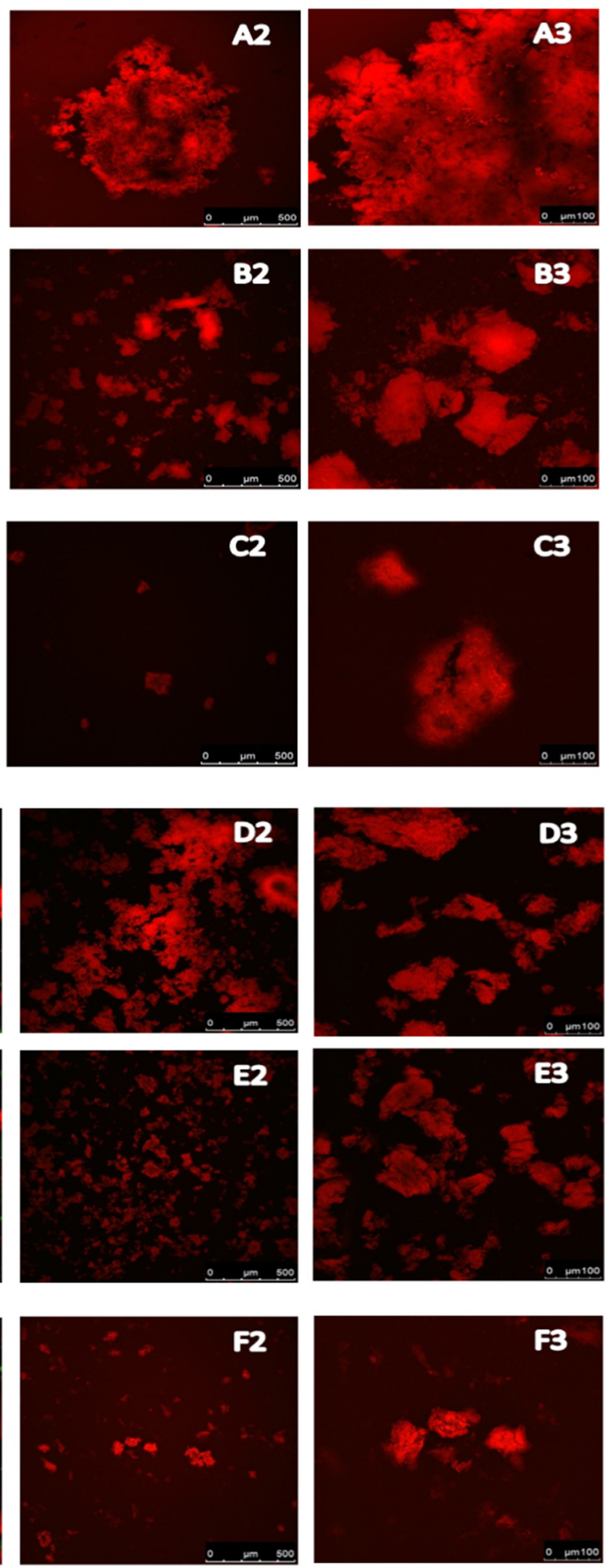

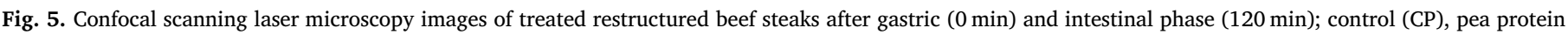
isolate (P), rice protein (R) and lentil flour (L) (at 4 and $8 \%$ ); binding agents: Activa ${ }^{\mathrm{EB}}$ (TG), and Trangluseen ${ }^{\mathrm{TM}}-\mathrm{M}$ (TS).

accessibility of the digestive juices, digestive proteolytic enzyme in particular. The following section illustrates the food micro-structure as examined by confocal scanning laser microscopy using advanced staining techniques.

After gastric phase: Cooking causes proteinaceous material to aggregate due to denaturation (Fig. 5A). CP, P4TG, P4TS, P8TS, R4TS, R8TG showed more a fine-stranded structure in comparison to R4TG,
R8TS and lentil-treated samples. P8TG showed protein agglomeration which may be due to the binder employed and not the inclusion level of pea protein isolate, as this effect was not observed in P8TS. The discontinuity of the formulation matrix of these samples could be as a result of fat coalescence due to the increased protein level, ingredienttype and tranglutaminase binder employed. Globular structures visible in the background might illustrate a so-called emulsion in a more 

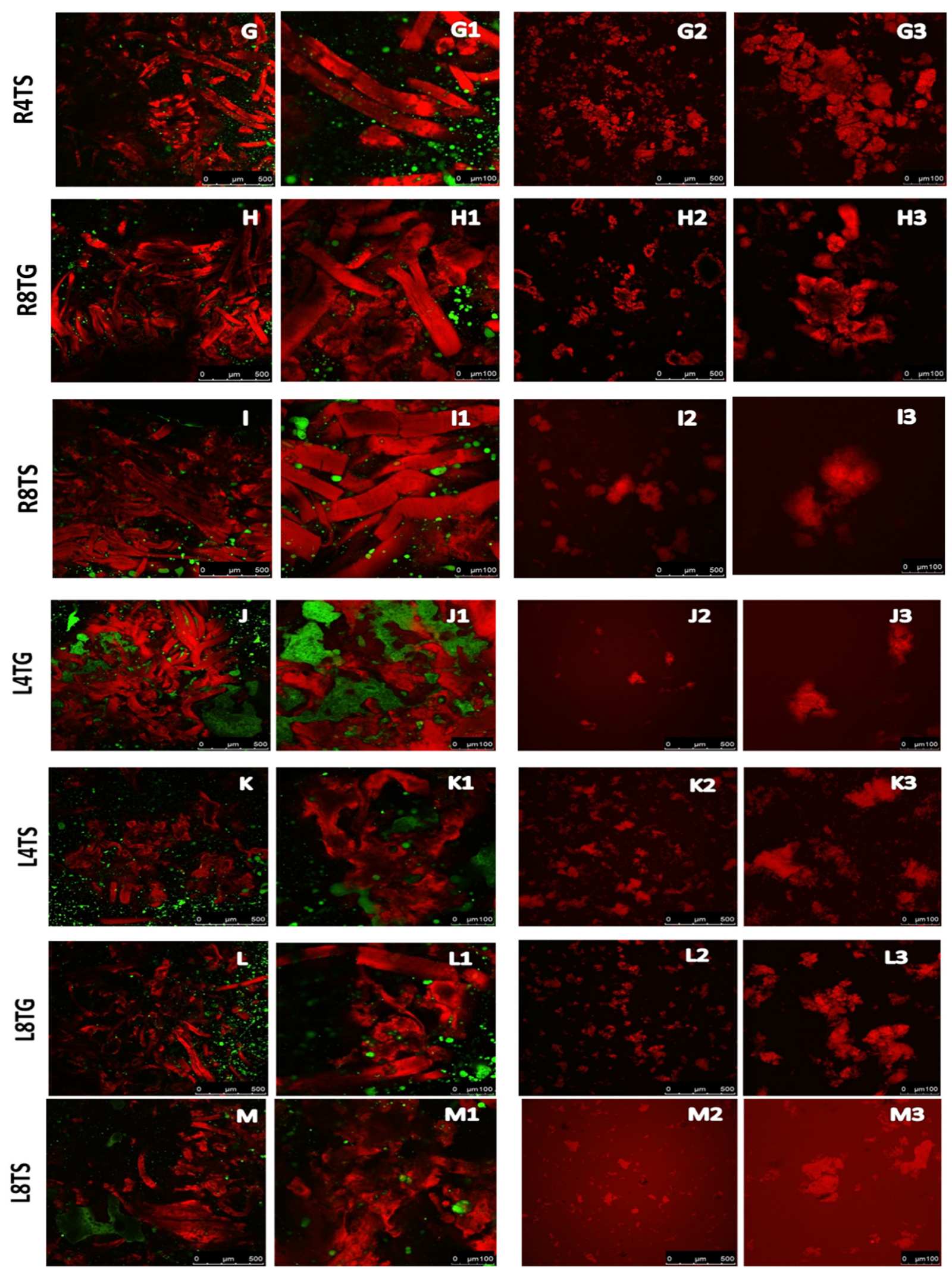

Fig. 5. (continued)

complicated colloidal system especially in P8TG and L4TG (Fig. 5D-J). It might also represent a variety of globular proteins components that are less solubilized and bound together by proteins that are more solubilized (Jones \& Mandigo, 1982). The morphology shows interstitial spaces, holding the filaments together and reinforcing the original network of the myofibril proteins. Fig. $5 \mathrm{~A}$ showed that cooking at $75^{\circ} \mathrm{C}$ causes/caused degradation of some of the filamentous structural integrity for parts of the image. This granular material formed may be related to partial precipitation of sarcoplasmic proteins from fluids that collect beneath the sarcolemma during fibre shrinkage (Fig. 5H1-I1). 
Amorphous and granulated surfaces due to protein coagulation were apparent at $60-71{ }^{\circ} \mathrm{C}$ in beef patties with added whey protein (ElMagoli, Larola, \& Hansen, 1995).

Inclusion of lentil flour resulted in a more compact structure as well as the presence of more free fat (Fig. 5J-M). This could be attributed to a loss in basic sarcomere structure, possibly because of the $\mathrm{pH}$-induced coagulation and denaturation of the actomyosin complex and other proteins. The enzymatic mechanism observed varied among all treated samples under gastro-intestinal conditions. This disruption as a result formed a fused matrix, which appeared to be unaffected to pepsin.

After intestinal phase: Gastric digestion appeared to have a severe effect on the microstructure of the meat product. In all treatments a complete disintegration of myofibrillar structure was observed. CP treatments presented more dense and compact cluster. Granular boluslike aggregates were observed with digestion time $(120 \mathrm{~min})$. All treatments except for control showed a distribution of aggregated protein clusters separated by irregular void spaces. These aggregates differed in sizes and density; in CP, P4TG and P8TG there aggregates were larger in comparison to the other treatments. At higher magnification, the clusters of aggregated proteins in pea and rice-treated restructured beef steaks were observed to be connected by fine fibres, forming a distinct network. Other samples had loosely packed aggregates. This is in line with Langton and Hermansson (1992) where when whey protein concentrate was added at $12 \%$ protein content to beef patties. In the intestinal phase it could be observed that control samples have a relatively compact structure and denser structure. It can be seen clearly that the structure of myofibrils became more amorphous and a pronounced shrinkage occurred.

Rice- and lentil treated samples still showed some agglomerates of smaller size when compared with the control, but with similar shape and size observed in gastric phase. It is possible that the level of protein ingredients used may act as filler or as a cementing agent (Comer \& Allan-Wojtas, 1988). The clusters formed were seen to be interconnected by fine strands, forming a distinct network. Clusters of aggregated protein linked together to various degrees in the enriched restructured beef steaks. This greater number of isolated protein aggregates linked to other protein aggregates was also observed by Yost and Kinsella (1992). The higher protein concentration, the closer and larger the aggregates became. This explains the role of plant-based ingredients when used as a water binder in a meat system.

\section{Conclusion}

In this study, meat was used as a protein source, but was fortified further to provide enhanced nutrition by the inclusion of plant-based proteins. This study examined the changes of a novel meat product following the addition of plant-based proteins and a transglutaminase enzyme at different time points and evaluates the protein degradation by using an in vitro digestion method suitable for food.

Micrographs of in vitro studies illustrated fibre separation during gastric digestion while fibre breakdown as well as protein re-aggregation was observed after intestinal digestion. In vitro digestates of protein-enriched restructured beef steaks showed lower susceptibility to the presence of small molecular weight peptides ranging between $0.5-1 \mathrm{kDa}$ and $<500 \mathrm{Da}$. Only lentil-enriched restructured beef steaks were found to have significant amounts of released, free amino acids namely isoleucine, lysine, phenylalanine and valine after GI digestion. Micrographs of digested samples revealed the insoluble food microstructure, which determines the accessibility of the digestive juices. It was observed that the addition of protein ingredients contributed to agglomeration of protein in the gastric phase, but which is then denatured in the intestinal phase resulting into smaller clusters or molecules. This gives an indication of how plant and meat proteins are influenced by digestive enzymes, the rate of digestive behaviour and their effect on the microstructure.

In summary, it would be important to carry out an optimisation study to adjust the level of plant proteins and transglutaminase enzyme so as to produce an optimised and technologically-acceptable formulation. This will not only help increase the nutritional quality of reformulated meat products but can also have a positive implication for human health, especially in the older adults. Future studies should also consider the identification of the protein bands by LC-MS/MS approach should provide more of an understanding of plant proteins during GI digestion along with their effect on the meat protein digestibility.

\section{Acknowledgements}

This research was funded by the FIRM programme administered under the Irish Department of Agriculture, Food and the Marine, Meat4Vitality (11/F/045): Enhancement of texture, flavour and nutritional value of meat products for older adults. S. Baugreet was funded under the Teagasc Walsh Fellowship Scheme. The authors also wish to acknowledge the contributions of Dr. Alice Joubran, Dr. Carlos Alvarez, Dr. Maria Hayes, Anne Marie McAuliffe, Sophie Gaspard, Sarah Lynch and Paula Reid.

\section{Conflict of interest}

The authors wish to declare no conflict of interest.

\section{References}

Baker, N. R., \& Blakely, K. K. (2017). Gastrointestinal disturbances in the elderly. Nursing Clinics of North America, 52(3), 419-431.

Barac, M., Cabrilo, S., Pesic, M., Stanojevic, S., Zilic, S., Macej, O., \& Ristic, N. (2010). Profile and functional properties of seed proteins from six pea (Pisum sativum) genotypes. International Journal of Molecular Sciences, 11(12), 4973-4990.

Baugreet, S., Kerry, J. P., Allen, P., Gallagher, E., \& Hamill, R. M. (2018). Physicochemical characteristics of protein-enriched beef steaks restructured with phosphates, transglutaminase and elasticised packaged forming. Journal of Food Quality, 2018, 1-11, 473602 .

Brodkorb, A., Egger, L., Alminger, M., Alvito, P., Assunção, R., Ballance, S., ... Recio, I. (2019). INFOGEST static in vitro simulation of gastrointestinal food digestion. Nature Protocols, 14(4), 991-1014.

Carballo, J., Ayo, J., \& Colmenero, F. J. (2006). Microbial transglutaminase and caseinate as cold set binders: Influence of meat species and chilling storage. LWT-Food Science and Technology, 39, 692-699.

Comer, Frederick W., \& Allan-Wojtas, Paula (1988). Functional and microstructural effects of fillers in comminuted meat products. Food Structure, 7(1) Article 4.

Damgaard, T., Lametsch, R., \& Otte, J. (2015). Antioxidant capacity of hydrolyzed animal by-products and relation to amino acid composition and peptide size distribution. Journal of Food Science and Technology, 52(10), 6511-6519.

El-Magoli, S. B., Larola, S., \& Hansen, P. M. T. (1995). Ultrastructure of low-fat ground beef patties with added whey protein concentrate. Food Hydrocolloids, 9(4), 291-306.

Friedman, M. (1996). Nutritional value of proteins from different food sources. A review. Journal of Agricultural and Food Chemistry, 44(1), 6-29.

Jones, K., \& Mandigo, R. (1982). Effects of chopping temperature on the microstructure of meat emulsions. Journal of Food Science, 47(6), 1930-1935.

Kaur, L., Maudens, E., Haisman, R. D., Boland, J. M., \& Singh, H. (2014). Microstructure and protein digestibility of beef: The effect of cooking conditions as used in stews and curries. LWT-Food Science and Technology, 55(2), 612-620.

Kaur, Rutherfurd, S. M., Moughan, P. J., Drummond, L., \& Boland, M. J. (2010). Actinidin enhances protein digestion in the small intestine as assessed using an in vitro digestion model. Journal of Agricultural and Food Chemistry, 58(8), 5074-5080.

Laemmli, U. K. (1970). Cleavage of structural proteins during the assembly of the head of bacteriophage T4. Nature, 227(5259), 680-685.

Langton, M., \& Hermansson, A.-M. (1992). Fine-stranded and particulate gels of $\beta$-lactoglobulin and whey protein at varying pH. Food Hydrocolloids, 5(6), 523-539.

Li, L., Liu, Y., Zou, X., He, J., Xu, X., Zhou, G., \& Li, C. (2017). In vitro protein digestibility of pork products is affected by the method of processing. Food Research International 92, 88-94.

McDermott, A., Visentin, G., De Marchi, M., Berry, D. P., Fenelon, M. A., O'Connor, P. M., \& McParland, S. (2016). Prediction of individual milk proteins including free amino acids in bovine milk using mid-infrared spectroscopy and their correlations with milk processing characteristics. Journal of Dairy Science, 99(4), 3171-3182.

Minekus, M., Alminger, M., Alvito, P., Ballance, S., Bohn, T., Bourlieu, C., \& Brodkorb, A. (2014). A standardised static in vitro digestion method suitable for food - an international consensus. Food \& Function, 5(6), 1113-1124.

Mintel (2013). \% share of clean label new product launches from new product launches in packaged food per country in. 2013.

Nowson, C., \& O'Connell, S. (2015). Protein requirements and recommendations for older people: A review. Nutrients, 7(8), 6874-6899.

Olmedilla-Alonso, B., Jiménez-Colmenero, F., \& Sánchez-Muniz, F. J. (2013). Development and assessment of healthy properties of meat and meat products 
designed as functional foods. Meat Science, 95, 919-930.

Opazo-Navarrete, M., Schutyser, M. A. I., Boom, R. M., \& Janssen, A. E. M. (2017). Effect of pre-treatment on in vitro gastric digestion of quinoa protein (Chenopodium quinoa Willd.) obtained by wet and dry fractionation. International Journal of Food Sciences and Nutrition, 1-11.

Pastor-Cavada, E., Juan, R., Pastor, J. E., Alaiz, M., \& Vioque, J. (2010). Protein isolates from two Mediterranean legumes: Lathyrus clymenum and Lathyrus annuus. Chemical composition, functional properties and protein characterisation. Food Chemistry, 122(3), 533-538.

Peng, I. C., Dayton, W. R., Quass, D. W., \& Allen, C. E. (1982). Investigations of soybean $11 \mathrm{~S}$ protein and myosin interaction by solubility, turbidity and titration studies. Journal of Food Science, 47(6), 1976-1983.

Pietrysiak, E., Smith, D. M., Smith, B. M., \& Ganjyal, G. M. (2018). Enhanced functionality of pea-rice protein isolate blends through direct steam injection processing. Food Chemistry, 243(Supplement C), 338-344.

Söderberg, J. (2013). Functional properties of legume proteins compared to egg proteins and their potential as egg replacers in vegan food.

Sullivan, L. M., Kehoe, J. J., Barry, L., Buckley, M. J. M., Shanahan, F., Mok, K. H., \& Brodkorb, A. (2014). (2014). Gastric digestion of $\alpha$-lactalbumin in adult human subjects using capsule endoscopy and nasogastric tube sampling. The British Journal of Nutrition, 112(4), 638-646.

Tahmasebi, M., Labbafi, M., Emam-Djomeh, Z., \& Yarmand, M. S. (2016). Manufacturing the novel sausages with reduced quantity of meat and fat: The product development, formulation optimization, emulsion stability and textural characterization. LWT-Food Science and Technology, 68, 76-84.

Tiwari, B. K., \& Singh, N. (2012). Pulse chemistry and technology. Cambridge: Royal Society of Chemistry.

Walrand, S., Gryson, C., Salles, J., Giraudet, C., Migné, C., Bonhomme, C., \& Boirie, Y. (2016). Fast-digestive protein supplement for ten days overcomes muscle anabolic resistance in healthy elderly men. Clinical Nutrition, 35(3), 660-668.

WHO/FAO/UNU (2007). Protein and amino acid requirementsin human nutrition, report of a joint WHO/FAO/UNU expert consultation. World Health Organization technical report Ser. 935. Geneva: WHO.

Wickham, M., Faulks, R., \& Mills, C. (2009). In vitro digestion methods for assessing the effect of food structure on allergen breakdown. Molecular Nutrition \& Food Research, 53(8), 952-958.

Woolnough, J. W., Bird, A. R., Monro, J. A., \& Brennan, C. S. (2010). The effect of a brief salivary $\alpha$-amylase exposure during chewing on subsequent in vitro starch digestion curve profiles. International Journal of Molecular Sciences, 11(8), 2780-2790.

Yost, R. A., \& Kinsella, J. (1992). Microstructure of whey protein isolate gels containing emulsified butterfat droplets. Journal of Food Science, 57(4), 892-897.

Youssef, M. K., \& Barbut, S. (2011). Fat reduction in comminuted meat products-effects of beef fat, regular and pre-emulsified canola oil. Meat Science, 87(4), 356-360. 